\title{
Influence of $\beta_{2}$-Microglobulin Expression on Gamma Interferon Secretion and Target Cell Lysis by Intraepithelial Lymphocytes during Intestinal Listeria monocytogenes Infection
}

\author{
MASASHI EMOTO, OLIVER NEUHAUS, YOSHIKO EMOTO, AND STEFAN H. E. KAUFMANN* \\ Department of Immunology, University of Ulm, D-89070 Ulm, Germany
}

Received 23 August 1995/Returned for modification 20 October 1995/Accepted 22 November 1995

\begin{abstract}
Numerous microbial pathogens, including Listeria monocytogenes, enter the host through the intestine. Although relatively little is known about the biological functions of intestinal intraepithelial lymphocytes (i-IEL), they are generally considered a first line of defense against intestinal infections. In the mouse, the vast majority of i-IEL express the CD8 coreceptor either as a CD8 $\alpha / \alpha$ homodimer or as a CD8 $\alpha / \beta$ heterodimer. The CD8 coreceptor of T-cell receptor $(\mathrm{TcR}) \gamma / \delta$ i-IEL is exclusively homodimeric, whereas the CD8-expressing $T c R \alpha / \beta$ i-IEL segregate into equal fractions of $C D 8 \alpha / \alpha$ and $C D 8 \alpha / \beta$ cells. We infected $\beta_{2}$-microglobulin $(\beta 2 \mathrm{~m})^{+/-}$mice (possessing all i-IEL populations) and $\beta 2 \mathrm{~m}^{-/-}$mutant mice (lacking all CD8 $\alpha / \beta^{+}$i-IEL and having few CD8 $\alpha / \alpha^{+}$TcR $\alpha / \beta$ i-IEL) with $L$. monocytogenes per os and determined their biological functions after TcR ligation with monoclonal antibodies. Cytolytic activities of TcR $\alpha / \beta$ and TcR $\gamma / \delta$ i-IEL from $\beta 2 m^{+/-}$ mice were not influenced by intestinal listeriosis. Cytolytic activities of TcR $\alpha / \beta$ i-IEL were impaired in uninfected $\beta 2 \mathrm{~m}^{-1-}$ mice, but this reduction was reestablished as a consequence of intestinal listeriosis. Frequencies of gamma interferon (IFN- $\gamma$ )-producing TcR $\alpha / \beta$ i-IEL in uninfected $\beta 2 \mathrm{~m}^{-/-}$mice were reduced, compared with that in their heterozygous controls. Equally low frequencies of IFN- $\gamma$-producing TcR $\gamma / \delta$ i-IEL in $\beta 2 \mathrm{~m}^{+/-}$and $\beta 2 \mathrm{~m}^{-/-}$mutants were found. Listeriosis increased frequencies of IFN- $\gamma$-producing TcR $\alpha / \beta$ and TcR $\gamma / \delta$ i-IEL in both mouse strains. Most remarkably, the proportion of IFN- $\gamma$-producing TcR $\gamma / \delta$ i-IEL was elevated 10 -fold in listeria-infected $\beta 2 \mathrm{~m}^{-1-}$ mice. Our findings show that the $\beta 2 \mathrm{~m}$-independent $\mathrm{CDB}^{-}$ i-IEL expressing either TcR $\alpha / \beta$ or TcR $\gamma / \delta$ are stimulated by intestinal listeriosis independent of regional $\beta 2 \mathrm{~m}$ expression. We conclude that the three major $\mathrm{CD8}^{+}$i-IEL populations are stimulated by intestinal listeriosis and that CD8 $\beta^{-}$i-IEL compensate for the total lack of CD8 ${ }^{+}$i-IEL in $\beta 2 \mathrm{~m}^{-/-}$mutant mice. Hence, in contrast to the peripheral immune system, which crucially depends on $\operatorname{CD8} \alpha / \beta^{+} \mathrm{TcR} \alpha / \beta$ lymphocytes, the mucosal immune system can rely on additional lymphocytes expressing the CD8 $\alpha / \alpha$ homodimer.
\end{abstract}

The intestinal mucosal surface is exposed to a wide variety of microorganisms. The so-called intestinal intraepithelial lymphocytes (i-IEL), which are located between epithelial cells, are considered a first line of defense which prevents translocation of the intestinal flora and interferes with host invasion by microbial pathogens. The i-IEL differ from the lymphocytes of the central immune system in various aspects. In particular, the i-IEL are characterized by a marked preponderance of CD8-expressing cells which represent more than two-thirds of the total i-IEL population $(14,18,20,30)$. In contrast to the $\mathrm{CD}^{+} \mathrm{T}$ lymphocytes of the central immune system which almost exclusively express the heterodimeric CD8 $\alpha / \beta$ coreceptor, the $\mathrm{CD}^{+}{ }^{+}$i-IEL segregate into two populations, expressing either a homodimeric $\mathrm{CD} 8 \alpha / \alpha$ or a heterodimeric $\mathrm{CD} 8 \alpha / \beta$ molecule $(14,18)$. The $C D 8 \alpha / \beta$ molecule is exclusively expressed by T-cell receptor $(\mathrm{TcR}) \alpha / \beta$ i-IEL, whereas the $\mathrm{CD} 8 \alpha / \alpha$ molecule is present on both $\operatorname{TcR} \alpha / \beta$ and $\operatorname{TcR} \gamma / \delta$ iIEL. In addition, some CD $4^{+} \mathrm{TcR} \alpha / \beta$ i-IEL, CD $4^{+} \mathrm{CD} 8^{+}$ $\mathrm{TcR} \alpha / \beta$ i-IEL, and $\mathrm{CD} 4^{-} \mathrm{CD}^{-}$(double negative) $\mathrm{TcR} \gamma / \delta$ i-IEL, as well as very few double-negative $\mathrm{TcR} \alpha / \beta$ i-IEL, exist $(13,18)$. The development and functional activation of $\mathrm{CD} 8 \alpha / \beta^{+} \mathrm{T}$ lymphocytes depends on surface expression of the major histocompatibility complex class I (MHC I)- $\beta_{2}$-micro-

\footnotetext{
* Corresponding author. Mailing address: Department of Immunology, University of Ulm, Albert-Einstein-Allee 11, D-89070 Ulm, Germany. Phone: (0731) 502-3361 or (0731) 502-3360. Fax: (0731) 5023367. Electronic mail address: Stefan.Kaufmann@Medizin.Uni-Ulm. DE.
}

globulin $(\beta 2 \mathrm{~m})$ complex $(46)$. Therefore, the $C D 8 \alpha / \beta^{+}$i-IEL are virtually absent from $\beta 2 \mathrm{~m}^{-1-}$ gene disruption mutant mice lacking surface-expressed MHC I- $\beta 2 \mathrm{~m}$ (49). In contrast, the $\mathrm{CD} 8 \alpha / \alpha$-expressing i-IEL develop virtually independently of $\beta 2 \mathrm{~m}$, although some influence of $\beta 2 \mathrm{~m}$ appears likely $(7,31$, $35)$. Thus far, it is unclear whether and how these $\beta 2 \mathrm{~m}$-independent $\mathrm{T}$ lymphocytes recognize antigenic ligands.

Experimental infection of mice with the intracellular bacterium Listeria monocytogenes has been widely used as a model for analyzing the mechanisms underlying cell-mediated immunity against intracellular pathogens (17). Most studies have restricted themselves to systemic infection. However, natural infection with L. monocytogenes is food borne, and therefore, i-IEL should provide a first line of defense against listerial invasion $(8,22,34)$. Despite their prominent location at the port of microbial entry into the host, relatively little is known about the role of i-IEL in host resistance. It has been shown that i-IEL from normal mice express high cytolytic activities and produce gamma interferon (IFN- $\gamma$ ) either spontaneously or after TcR ligation by monoclonal antibodies (MAb) $(10,42$, 44). Although preactivation of i-IEL by the normal intestinal flora has been suggested, the influence of intestinal bacterial invasion on the biological activities of $\mathrm{i}$-IEL remains to be investigated (2).

In the present study, we have analyzed the influence of per os (p.o.) infection with L. monocytogenes on the major i-IEL populations by comparing i-IEL activities from $\beta 2 \mathrm{~m}^{-/-}$and $\beta 2 \mathrm{~m}^{+/-}$mice after TcR stimulation with specific MAb. The absence of $\beta 2 \mathrm{~m}$ expression reduced overall cytolytic activities 
of and IFN- $\gamma$ production by $\mathrm{TcR} \alpha / \beta$ i-IEL, probably as a consequence of the loss of $\mathrm{CD} 8 \alpha / \beta$-expressing cells. Intestinal listeriosis increased cytolytic activities and IFN- $\gamma$ production by $\mathrm{TcR} \alpha / \beta$ and TcR $\gamma / \delta$ i-IEL in $\beta 2 \mathrm{~m}^{-/-}$mutants, suggesting that intestinal listeriosis activated these i-IEL independently from $\beta 2 \mathrm{~m}$-contingent antigen presentation. Our findings provide evidence that $\mathrm{CD} 8 \alpha / \beta^{+} \operatorname{TcR} \alpha / \beta$ i-IEL, $\mathrm{CD} 8 \alpha / \alpha^{+} \operatorname{TcR} \alpha / \beta$ i-IEL, and CD $8 \alpha / \alpha^{+}$TcR $\gamma / \delta$ i-IEL contribute to regional host defense against intestinal infection with bacterial pathogens.

\section{MATERIALS AND METHODS}

Animals. Breeding pairs of $\beta 2 \mathrm{~m}^{-1-}$ mice were a kind gift of R. Jaenisch (49). Homozygous or heterozygous mutants on C57BL/6 background ( $>$ sixth back cross) of either sex were used at 10 to 12 weeks of age.

Microorganisms and infection. L. monocytogenes EGD organisms were maintained virulent by passage in mice. A sample of liver homogenates was grown in tryptic soy broth at $37^{\circ} \mathrm{C}$ for $18 \mathrm{~h}$, and aliquots were frozen at $-70^{\circ} \mathrm{C}$ until used. The concentration of bacteria was quantitated by plate counts. Mice were starved for $4 \mathrm{~h}$ and then infected p.o. with $10^{8}$ L. monocytogenes organisms with a gastric tube.

Cell preparation. The i-IEL were prepared as described previously with slight modifications (16). Briefly, a plastic stick was introduced into the lumen of the small intestine, and the gut was fixed with a thread and inverted. The inverted small intestines were placed in a bottle containing Click's RPMI 1640 complete medium, and the bottle was agitated on an orbital shaker at $37^{\circ} \mathrm{C}$ for $30 \mathrm{~min}$. Supernatants were collected, and the gut tissue was transferred to a $50-\mathrm{ml}$ tube containing $15 \mathrm{ml}$ of medium and vortexed vigorously. This procedure was repeated twice, and supernatants were collected each time. Purified i-IEL were prepared by passage through a $10-\mathrm{ml}$ syringe loosely packed with glass wool (150 mg; Serva Feinbiochemica, Heidelberg, Germany) and separation over discontinuous Percoll density gradients $(1.124 \mathrm{~g} / \mathrm{ml}$; Seromed, Berlin, Germany). Gradients were prepare in $10-\mathrm{ml}$ centrifuge tubes by layering from the bottom $70 \%$ Percoll $(2 \mathrm{ml})$ and then $40 \%$ Percoll $(3 \mathrm{ml})$ containing cells. The tubes were then centrifuged at $600 \times g$ for $25 \mathrm{~min}$. The interface between the $40 \%$ and the $70 \%$ layer containing lymphocytes of $>95 \%$ cell viability was collected and washed.

MAb. The following hybridomas were used for MAb preparation: anti-TcR $\alpha / \beta$ MAb (H57-597) (19); anti-TcR $\gamma / \delta$ MAb (GL3) (11); anti-CD3 $\varepsilon$ MAb (1452C11) (21); anti-CD8ß MAb (H35-17.2) (9); anti-IFN- $\gamma$ MAb (R4-6A2 [39] and AN18.17.24 [32]). Hybridoma cells were cultured in medium containing $2 \%$ fetal calf serum, and supernatants were collected. The MAb were then concentrated by ammonium sulfate precipitation and purified by affinity chromatography on protein A or G Sepharose (Pharmacia, Freiburg, Germany). Anti-TcR $\alpha / \beta$ MAb, anti-TcR $\gamma / \delta$ MAb, and anti-IFN- $\gamma$ MAb (AN18.17.24) were conjugated with biotin. Anti-CD8 $\beta$ MAb were conjugated with fluorescein isothiocyanate by conventional methods. Phycoerythrin-conjugated anti-CD4 MAb (H129.19) and streptavidin-conjugated-Red 670 were purchased from Gibco (Gaithersburg, Md.). FITC-conjugated anti-CD8 $\alpha$ MAb (YTS 169.4) were obtained from Medac (Hamburg, Germany). Normal hamster immunoglobulin (Ig) was purchased from Dianova (Hamburg, Germany)

Redirected cytolytic assay. The i-IEL were assayed for cytolytic activities against ${ }^{51}$ Cr-labelled P815 target cells as described previously (44, 47). Briefly, serial dilutions of i-IEL were incubated in 96-well V-bottom plates with $10^{3}$ ${ }^{51}$ Cr-labelled P815 target cells in the presence or in the absence of anti-CD3 $\mathrm{MAb}$, anti-TcR $\alpha / \beta \mathrm{MAb}$, anti-TcR $\gamma / \delta \mathrm{MAb}$, or normal hamster Ig at $2 \mu \mathrm{g} / \mathrm{ml}$ for $4 \mathrm{~h}$. After incubation, $100 \mu \mathrm{l}$ of supernatants was collected from each well and radioactivity was determined with a gamma counter (Cobra, Canberra Packard, Germany). Percent specific killing was calculated as follows: [(experimental ${ }^{51} \mathrm{Cr}$ release - spontaneous ${ }^{51} \mathrm{Cr}$ release $) /\left(\right.$ maximum ${ }^{51} \mathrm{Cr}$ release - spontaneous ${ }^{51} \mathrm{Cr}$ release)] $\times 100$. Spontaneous release was always $<10 \%$ of total ${ }^{51} \mathrm{Cr}$ incorporated into target cells.

ELISPOT assay. MAb-facilitated IFN- $\gamma$ production by i-IEL was measured by the enzyme-linked immunospot (ELISPOT) assay as described previously ( 24 43). Briefly, ELISPOT plates (Millipore, Eschborn, Germany) were coated with anti-IFN- $\gamma$ MAb (R4-6A2, $1 \mu \mathrm{g} / \mathrm{ml})$ in $100 \mu \mathrm{l}$ of $0.05 \mathrm{M}$ carbonate buffer $(\mathrm{pH}$ 9.6) per well at $4^{\circ} \mathrm{C}$ overnight. The coating buffer was then removed, and the plates were dried at room temperature for $1 \mathrm{~h}$. The plates were washed twice with phosphate-buffered saline (PBS) and blocked with PBS containing $1 \%$ bovine serum albumin (BSA) at $37^{\circ} \mathrm{C}$ for $2 \mathrm{~h}$. After the plates were washed twice with PBS, various concentrations of i-IEL and $10^{4} \mathrm{P} 815$ cells were cultured at $37^{\circ} \mathrm{C}$ overnight with $2 \mu \mathrm{g}$ of anti-CD3 MAb, anti-TcR $\alpha / \beta \mathrm{MAb}$, anti-TcR $\gamma / \delta \mathrm{MAb}$, normal hamster Ig, or medium alone per $\mathrm{ml}$. The plates were then washed 10 times with PBS and 10 times with PBS containing 0.05\% Tween 20 (washing buffer) and incubated with $0.25 \mu \mathrm{g}$ of biotin-conjugated anti-IFN- $\gamma$ MAb (AN18.17.24) per $\mathrm{ml}$ at $37^{\circ} \mathrm{C}$ for $2 \mathrm{~h}$. The plates were then washed 20 times with washing buffer, and streptavidin-conjugated alkaline phosphatase $(1: 20,000$ in PBS containing $0.1 \% \mathrm{BSA}$ ) was added. After $1 \mathrm{~h}$ of incubation at $37^{\circ} \mathrm{C}$, the plates were washed eight times with washing buffer and twice with alkaline phosphatase buffer. The substrate, 5-bromo-4-chloro-3-indolyl phosphate (Fluka, Basel, Swit- zerland), and the catalyst, nitroblue tetrazolium chloride (Fluka), were then added, and the plates were incubated at $37^{\circ} \mathrm{C}$ in the dark for $15 \mathrm{~min}$. The plates were washed with distilled water and dried, and spots were counted by using a dissecting microscope.

Flow cytometry. Single-cell suspensions were stained with fluorescein isothiocyanate-conjugated MAb, phycoerythrin-conjugated MAb, and biotin-conjugated MAb, followed by staining with streptavidin-conjugated Red 670. All incubation steps were performed at $4^{\circ} \mathrm{C}$ for $30 \mathrm{~min}$, and all washing steps were performed with PBS containing $2.5 \%$ normal human serum and $0.1 \%$ sodium azide. After being stained, the cells were fixed with $1 \%$ paraformaldehyde (Serva) and $10^{4}$ cells were analyzed with a FACScan (Becton Dickinson, Sunnyvale, Calif.) equipped with a data lister and Lysis II software. Live cells were gated by forward and side scatter. Analysis gate was set on $\mathrm{TcR} \alpha / \beta$ or $\mathrm{TcR} \gamma / \delta$ cells, and CD4/CD8 expression was displayed.

Histological study. Numbers of i-IEL per $10^{3}$ epithelial cells were counted microscopically in tissue sections of the duodenum after staining with periodic acid-Schiff stain (PAS).

Statistical analysis. Data from different experimental groups were compared by Student's $t$ test.

\section{RESULTS}

Influence of intestinal listeriosis on IFN- $\gamma$-producing $\mathrm{i}$-IEL from $\boldsymbol{\beta 2} \mathrm{m}^{-1-}$ and $\boldsymbol{\beta} 2 \mathrm{~m}^{+/-}$mice. We assessed frequencies of IFN- $\gamma$-producing i-IEL from $\beta 2 \mathrm{~m}^{-/-}$and $\beta 2 \mathrm{~m}^{+/-}$mice during intestinal L. monocytogenes infection. The i-IEL were stimulated with anti-CD3 MAb, anti-TcR $\alpha / \beta \mathrm{MAb}$, or anti-TcR $\gamma / \delta$ $\mathrm{MAb}$ in the presence of P815 cells. High frequencies of IFN$\gamma$-producing i-IEL were induced in uninfected $\beta 2 \mathrm{~m}^{+/-}$mice by anti-CD3 MAb or anti-TcR $\alpha / \beta$ MAb, whereas in i-IEL from $\beta 2 \mathrm{~m}^{-1-}$ mice, numbers of IFN- $\gamma$ producers were significantly $(P<0.01)$ decreased (Table 1$)$. Anti-TcR $\gamma / \delta \mathrm{MAb}$ caused a slight though statistically significant $(P<0.05)$ increase in IFN- $\gamma$ production in both $\beta 2 \mathrm{~m}^{+/-}$and $\beta 2 \mathrm{~m}^{-1-}$ mice. Thus, the few $\mathrm{CD} 8 \beta^{-} \mathrm{TcR} \alpha / \beta$ i-IEL present in $\beta 2 \mathrm{~m}^{-1-}$ mutants were potent IFN- $\gamma$ producers, whereas only few TcR $\gamma / \delta$ i-IEL produced IFN- $\gamma$ in response to TcR ligation, regardless of the presence or absence of $\beta 2 \mathrm{~m}$. Consistent with results obtained with $\mathrm{C} 57 \mathrm{BL} / 6$ mice (47), frequencies of spontaneous IFN- $\gamma$ producing i-IEL were significantly $(P<0.01)$ elevated during intestinal L. monocytogenes infection (Table 1). CD3 or $\mathrm{TcR} \alpha / \beta$ ligation by specific MAb increased frequencies of IFN- $\gamma$ producers in $L$. monocytogenes-infected $\beta 2 \mathrm{~m}^{+/-}$and $\beta 2 \mathrm{~m}^{-1-}$ mice $(P<0.01)$. These findings suggest that in immunocompetent mice, both $\mathrm{CD} 8 \beta^{+}$and $\mathrm{CD} 8 \beta^{-} \mathrm{TcR} \alpha / \beta$ i-IEL are potent IFN- $\gamma$ producers and that in both i-IEL populations IFN- $\gamma$ secretion is further stimulated by intestinal listeriosis. Most remarkably, L. monocytogenes infection caused a 10 -fold increase $(P<0.001)$ in the frequencies of IFN- $\gamma$-producing TcR $\gamma / \delta$ i-IEL in $\beta 2 \mathrm{~m}^{-/-}$mutants, whereas in $\beta 2 \mathrm{~m}^{+/-}$mice only a slight increase $(<3$-fold, $P<0.05)$ was observed. As a result, during listeriosis, frequencies of IFN- $\gamma$-producing TcR $\gamma / \delta$ i-IEL were higher in $\beta 2 \mathrm{~m}^{-/-}$mice than in $\beta 2 \mathrm{~m}^{+/-}$ mice. We conclude that intestinal listeriosis activates IFN- $\gamma$ secretion in all major i-IEL populations. Although we assume that listerial invasion activated IFN- $\gamma$-producing TcR $\gamma / \delta$ i-IEL more potently in the absence than in the presence of $\beta 2 \mathrm{~m}$, we cannot exclude a compensatory increase in the frequency of IFN- $\gamma$-producing TcR $\gamma / \delta$ i-IEL in $\beta 2 \mathrm{~m}^{-/-}$mutants.

Influence of intestinal listeriosis on target cell lysis by i-IEL from $\boldsymbol{\beta} 2 \mathrm{~m}^{-1-}$ and $\boldsymbol{\beta} 2 \mathrm{~m}^{+/-}$mice. Next, the effect of $L$. monocytogenes invasion on cytolytic activities of i-IEL from $\beta 2 \mathrm{~m}^{-/-}$ and $\beta 2 \mathrm{~m}^{+/-}$mice were studied in MAb-facilitated ${ }^{51} \mathrm{Cr}$ release assays by using MAb with a specificity for $\mathrm{CD} 3, \mathrm{TcR} \alpha / \beta$, or $\mathrm{TcR} \gamma / \delta$. Consistent with previous findings $(11,12)$, strong cytolytic activities were induced in i-IEL from $\beta 2 \mathrm{~m}^{+/-}$mice, and $\mathrm{TcR} \alpha / \beta$ i-IEL were more potent than TcR $\gamma / \delta$ i-IEL $(P<0.01)$ (Fig. 1). In $\beta 2 \mathrm{~m}^{+/-}$controls, target cell lysis by TcR $\alpha / \beta$ and by $\mathrm{TcR} \gamma / \delta$ i-IEL remained virtually unchanged under intestinal $L$. monocytogenes infection. Cytolytic activities of $\mathrm{TcR} \alpha / \beta$ i-IEL 
TABLE 1. Enumeration of IFN- $\gamma$-producing cells among i-IEL from $\beta 2 \mathrm{~m}^{-/-}$and $\beta 2 \mathrm{~m}^{+/-}$mice and influence of intestinal L. monocytogenes infection ${ }^{a}$

\begin{tabular}{|c|c|c|c|c|}
\hline \multirow{3}{*}{ Stimulation } & \multicolumn{4}{|c|}{ IFN- $\gamma$-producing cells $/ 10^{6}$ i-IEL } \\
\hline & \multicolumn{2}{|c|}{ Uninfected } & \multicolumn{2}{|c|}{ Infected } \\
\hline & $\beta 2 \mathrm{~m}^{+/-}$ & $\beta 2 \mathrm{~m}^{-/-}$ & $\beta 2 \mathrm{~m}^{+/-}$ & $\beta 2 \mathrm{~m}^{-1-}$ \\
\hline Anti-CD3 MAb & $14,500 \pm 1,852^{b}$ & $6,813 \pm 744^{b, c}$ & $32,100 \pm 5,242^{b, c}$ & $13,600 \pm 1,633^{b, d}$ \\
\hline Anti-TcR $\alpha / \beta$ MAb & $13,600 \pm 1,943^{b}$ & $5,363 \pm 791^{b, c}$ & $27,000 \pm 4,650^{b, c}$ & $12,575 \pm 1,572^{b, d}$ \\
\hline Anti-TcR $\gamma / \delta$ MAb & $525 \pm 82^{e}$ & $613 \pm 44^{e}$ & $1,375 \pm 252^{c, e}$ & $5,975 \pm 698^{b, f}$ \\
\hline Hamster Ig & $250 \pm 30$ & $225 \pm 14$ & $850 \pm 103^{c}$ & $925 \pm 171^{d}$ \\
\hline P815 alone & $263 \pm 18$ & $250 \pm 22$ & $800 \pm 105^{c}$ & $863 \pm 108^{d}$ \\
\hline None & $225 \pm 28$ & $225 \pm 19$ & $738 \pm 111^{c}$ & $800 \pm 118^{d}$ \\
\hline
\end{tabular}

${ }^{a}$ Mice were infected p.o. with $10^{8}$ L. monocytogenes organisms and i-IEL were prepared on day 0 and day 8 postinfection. The i-IEL $\left(10^{6}\right)$ and P815 cells $\left(10^{4}\right)$ were incubated with MAb overnight in ELISPOT plates coated with anti-IFN- $\gamma$ MAb. Shown are representative results from three different experiments. Results are means \pm standard deviations of triplicate cultures. Mean numbers of spots per $10^{6}$ cells in controls: without coating anti-IFN- $\gamma$ MAb, $25 \pm 5$; without biotin-conjugated MAb, $38 \pm 6 ;$ P815 alone, $63 \pm 10$.

${ }^{b}$ Significant difference relative to unstimulated i-IEL at $P<0.001$ at $P<0.01$.

${ }^{c}$ Significant difference relative to uninfected $\beta 2 \mathrm{~m}^{+/-}$mice.

${ }^{d}$ Significant difference relative to uninfected $\beta 2 \mathrm{~m}^{-/-}$mice at $P<0.01$.

${ }^{e}$ Significant difference relative to unstimulated i-IEL at $P<0.05$.

${ }^{f}$ Significant difference relative to uninfected $\beta 2 \mathrm{~m}^{-1-}$ mice at $P<0.001$.

were markedly reduced in uninfected $\beta 2 \mathrm{~m}^{-1-}$ mice $(P<0.01)$, whereas those of TcR $\gamma / \delta$ i-IEL remained unaffected by the $\beta 2 \mathrm{~m}$ deficiency. Intestinal $L$. monocytogenes infection, however, strongly increased target cell lysis by $\mathrm{TcR} \alpha / \beta$ and $\mathrm{TcR} \gamma / \delta$ i-IEL from $\beta 2 \mathrm{~m}^{-1-}$ mutants $(P<0.01)$ (Fig. 1$)$. Our results suggest that intestinal listeriosis stimulated cytolytic activities in $\operatorname{CD} 8 \beta^{-} \mathrm{TcR} \alpha / \beta$ and TcR $\gamma / \delta$ i-IEL from $\beta 2 \mathrm{~m}^{-1-}$ mice.

Time course of i-IEL activation from $L$. monocytogenes-infected $\beta 2 \mathrm{~m}^{-1-}$ and $\beta 2 \mathrm{~m}^{+/-}$mice. The $\beta 2 \mathrm{~m}^{-/-}$and $\beta 2 \mathrm{~m}^{+/-}$ mice were infected p.o. with $L$. monocytogenes, and i-IEL were prepared at different time points thereafter. As shown in Fig. 2 , target cell lysis by $\mathrm{TcR} \alpha / \beta$ and $\mathrm{TcR} \gamma / \delta$ i-IEL remained virtually unchanged in $\beta 2 \mathrm{~m}^{+/-}$mice during the course of infection. In contrast, intestinal $L$. monocytogenes infection gradually increased cytolytic activities by TcR $\alpha / \beta$ and TcR $\gamma / \delta$ i-IEL in $\beta 2 \mathrm{~m}^{-1-}$ mice. Although frequencies of IFN- $\gamma$-producing $\operatorname{TcR} \alpha / \beta$ and $\operatorname{TcR} \gamma / \delta$ i-IEL were instantaneously elevated by intestinal listeriosis in both $\beta 2 \mathrm{~m}^{-/-}$and $\beta 2 \mathrm{~m}^{+/-}$mice, listeriosis had the strongest effects on IFN- $\gamma$ production by $\mathrm{TcR} \gamma / \delta$ i-IEL from $\beta 2 \mathrm{~m}^{-1-}$ mice: already at day 2 of infection, a 10 -fold increase was observed. Thus, activation of IFN- $\gamma$-producing TcR $\gamma / \delta$ i-IEL preceded stimulation of cytolytic TcR $\alpha / \beta$ i-IEL in L. monocytogenes-infected $\beta 2 \mathrm{~m}^{-1-}$ mutant mice.

Numbers and phenotypes of i-IEL from $L$. monocytogenesinfected $\boldsymbol{\beta} 2 \mathrm{~m}^{-1-}$ and $\boldsymbol{\beta} 2 \mathrm{~m}^{+/-}$mice. The influence of $\beta 2 \mathrm{~m}$ expression and of intestinal listeriosis on numbers and phenotypes of i-IEL was assessed. The ratio of the total i-IEL to epithelial cells was determined first. Duodenal tissue sections were stained with PAS, in each section $10^{3}$ epithelial cells were counted, and numbers of lymphoid cells within the epithelial layer inside the PAS-positive basal lamina were determined. In $\beta 2 \mathrm{~m}^{+/-}$mice, $14.2 \%$ of total epithelial cells were i-IEL, and intestinal listeriosis slightly increased this proportion to $16.6 \%$. In $\beta 2 \mathrm{~m}^{-1-}$ mutants, the percentage of i-IEL among total epithelial cells was modestly increased from $13.6 \%$ to $18.0 \%$ during infection. In both cases, however, these increases were not statistically significant. In contrast, total cell numbers recovered after preparation of i-IEL were decreased during intestinal L. monocytogenes infection from $11.0 \times 10^{6}$ to $5.8 \times$ $10^{6} \mathrm{i}$-IEL in $\beta 2 \mathrm{~m}^{+/-}$control mice $(P<0.01)$ and from $8.2 \times$ $10^{6}$ to $4.2 \times 10^{6} \mathrm{i}$-IEL in $\beta 2 \mathrm{~m}^{-1-}$ mutants $(P<0.01)$. Although we cannot explain this discrepancy, we consider two alternative explanations. It is possible that listerial invasion selectively destroyed columnar epithelial cells, thus increasing the relative proportion of i-IEL in PAS-stained sections. Alternatively, it is possible that intestinal listeriosis rendered i-IEL more susceptible to the in vitro preparation procedure, thus causing their selective loss. In the next experiment, i-IEL were characterized phenotypically by flow cytometry. Consistent with previous data $(26,49)$, in $\beta 2 \mathrm{~m}^{-1-}$ mutants $\mathrm{CD} 8 \alpha / \beta^{+} \mathrm{TcR} \alpha / \beta$ i-IEL were absent (Table 2). Moreover, the CD $8 \alpha / \alpha^{+} \mathrm{TcR} \alpha / \beta$ i-IEL population was markedly reduced in $\beta 2 \mathrm{~m}^{-/-}$mutant mice (7, $26,31,35)$. Importantly, intestinal listeriosis had only negligible effects on the relative proportions of the various i-IEL populations, regardless of its marked influence on the biological activities of CD8 $\beta^{-}$i-IEL (Table 2). It is possible that the activation of these i-IEL during listerial invasion occurred virtually independently of i-IEL expansion. Alternatively, it is conceivable that intestinal listeriosis caused expansion of listeria-reactive i-IEL without affecting the overall homeostasis of the various i-IEL populations and that preactivated listeriareactive i-IEL expressed more potent biological activities in response to $\mathrm{TcR}$ engagement.

\section{DISCUSSION}

L. monocytogenes is an intracellular pathogen which has been instrumental in elucidating the mechanisms of central cell-mediated antibacterial immunity (17). Although CD8 $\alpha / \beta^{+}$ $\mathrm{TcR} \alpha / \beta$ cells are essential for protective immunity, both $\mathrm{TcR} \gamma / \delta$ cells and $\mathrm{CD} 4^{+} \mathrm{TcR} \alpha / \beta$ cells contribute to optimum protection in addition (17). IFN- $\gamma$ and target cell lysis are considered crucial for sterile clearance of the pathogen (17). Listeriosis is a relatively rare disease of humans, but foodborne outbreaks are being increasingly noted $(8,22,34)$. It is reasonable to assume that mucosal immunity provides a first line of defense against listerial outbreaks. For this reason, we have started to analyze the role of i-IEL in mucosal protection, using the model of p.o. infection of mice with L. monocytogenes. Previous studies from our group have already suggested that intestinal listeriosis stimulates IFN- $\gamma$ production in $\mathrm{TcR} \gamma / \delta$ i-IEL of immunocompetent mice (47).

The vast majority $(>80 \%)$ of all i-IEL express the CD8 coreceptor $(14,18,20,30)$. Approximately one-third of these $\mathrm{CD}^{+}{ }^{+} \mathrm{i}$-IEL possess the CD8 $\alpha / \beta$ heterodimer and about twothirds possess the $\mathrm{CD} 8 \alpha / \alpha$ homodimer $(14,18)$. While the 
$\mathrm{B} 2 \mathrm{~m}^{+/}$(Uninfected)

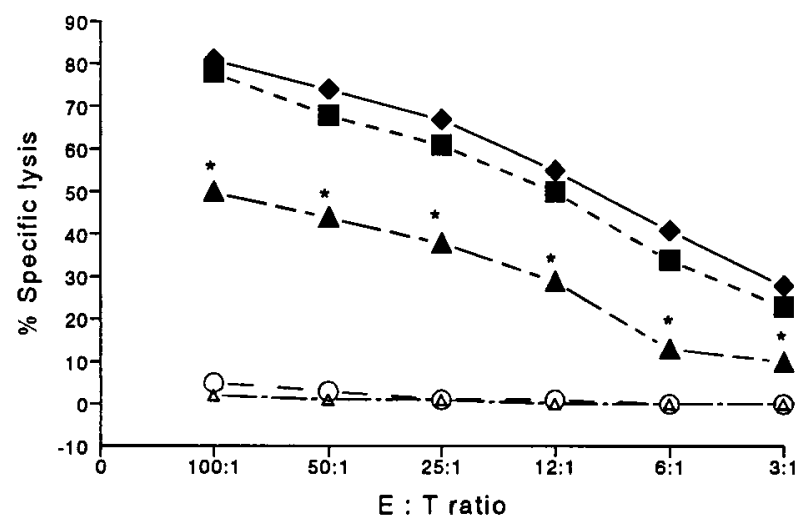

$B 2 m^{-1}$ (Uninfected)

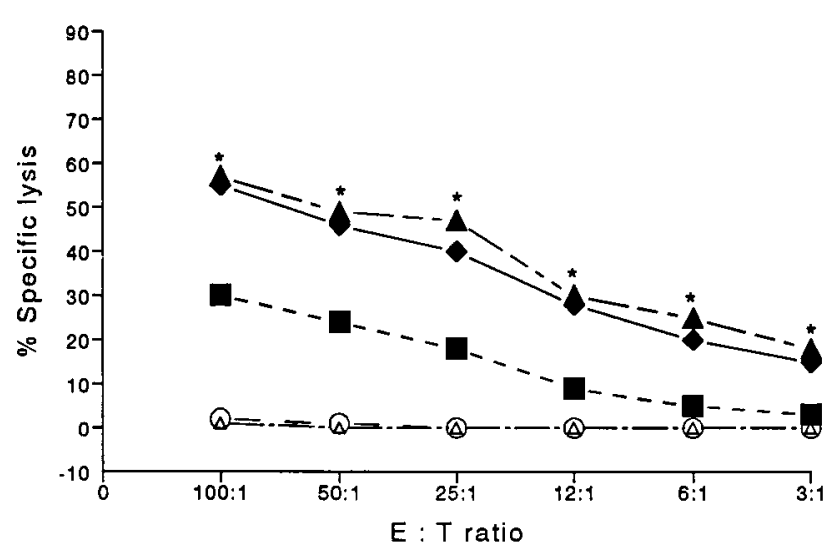

$\mathrm{B2} \mathrm{m}^{+/-}$(Infected)

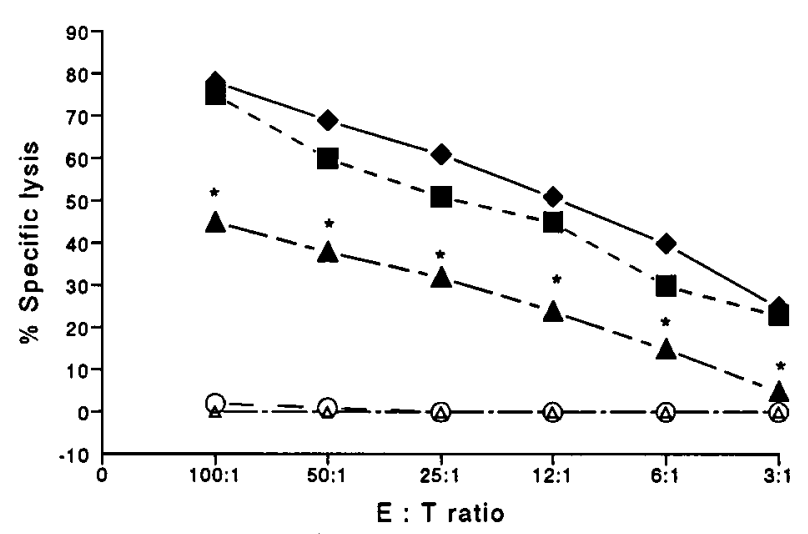

B2m $\%$ (Infected)

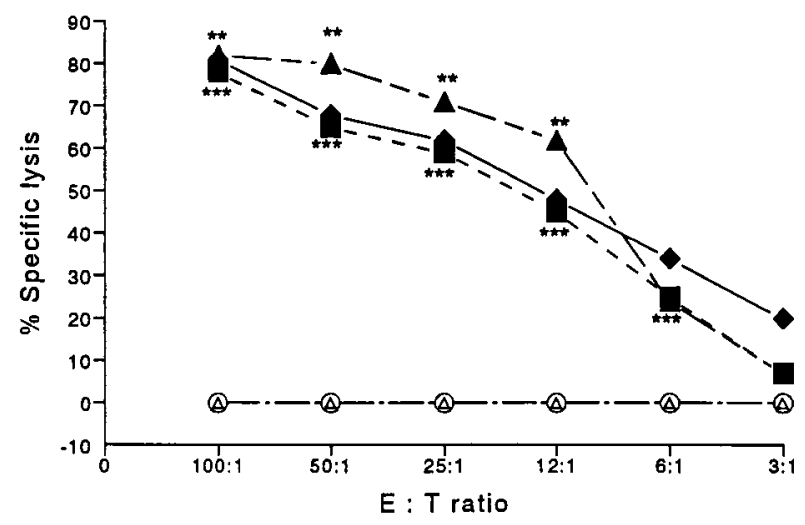

FIG. 1. Cytotoxic activities of i-IEL from $\beta 2 \mathrm{~m}^{-/-}$or $\beta 2 \mathrm{~m}^{+/-}$mutant mice and influence of intestinal L. monocytogenes infection. Mice were infected p.o. with $10^{8}$ L. monocytogenes organisms. The i-IEL were prepared on day 0 or day 8 of infection and assayed for cytolytic activities against ${ }^{51} \mathrm{Cr}$-labelled P815 cells in the presence of anti-CD3 MAb $(\bullet)$, anti-TcR $\alpha / \beta$ MAb $(\boldsymbol{\square})$, anti-TcR $\gamma / \delta \mathrm{MAb}(\boldsymbol{\Delta})$, or normal hamster $\operatorname{Ig}(\bigcirc)$ or in the absence of MAb $(\triangle)$. Results were plotted as percent specific lysis at various effector-to-target (E:T) ratios. Representative results for a total of six mice per group are shown. $*$, significant difference relative to TcR $\alpha / \beta$ engagement at $P<0.01$. ** and $* * *$, significant difference relative to uninfected $\beta 2 \mathrm{~m}^{-1-}$ mice at $P<0.05$ and $P<0.01$, respectively.

former population resides exclusively in the TcR $\alpha / \beta$ i-IEL population, the latter subset segregates into approximately equal proportions of $\mathrm{TcR} \alpha / \beta$ and TcR $\gamma / \delta$ cells. The $\mathrm{CD} 8 \alpha / \beta^{+} \mathrm{i}-\mathrm{IEL}$ are strictly $\beta 2 \mathrm{~m}$ dependent, whereas the CD $8 \alpha / \alpha^{+}$i-IEL are virtually $\beta 2 \mathrm{~m}$ independent $(7,31,35,49)$. Therefore, $\beta 2 \mathrm{~m}^{-1-}$ and $\beta 2 \mathrm{~m}^{+/-}$mutant mice allowed us to study the influences of listeriosis on the three major i-IEL populations, namely $\mathrm{CD} 8 \alpha / \alpha^{+} \mathrm{TcR} \alpha / \beta$ i-IEL, CD $8 \alpha / \beta^{+} \mathrm{TcR} \alpha / \beta$ i-IEL, and $\mathrm{CD} 8 \alpha / \alpha^{+} \mathrm{TcR} \gamma / \delta$ i-IEL. We determined total cytolytic activities and frequencies of IFN- $\gamma$-producing cells following TcR engagement to assess the influence of intestinal listeriosis on i-IEL populations irrespective of their antigen specificity.

Consistent with previous studies $(7,26,31,35)$, flow cytometric analysis of i-IEL from $\beta 2 \mathrm{~m}^{+/-}$and $\beta 2 \mathrm{~m}^{-1-}$ mice revealed not only a strict $\beta 2 \mathrm{~m}$ dependence of CD $8 \alpha / \beta^{+}$i-IEL but also a strong influence on the $\mathrm{CD} 8 \alpha / \alpha^{+} \mathrm{TcR} \alpha / \beta$ i-IEL though not on the CD $8 \alpha / \alpha^{+}$TcR $\gamma / \delta$ i-IEL. Complete loss of CD $8 \beta^{+}$ cells and marked diminution in the $\mathrm{CD} 8 \beta^{-}$population caused dramatic reduction of the total TcR $\alpha / \beta$ i-IEL population and a relative increase in the $T c R \gamma / \delta$ i-IEL population in $\beta 2 \mathrm{~m}^{-/-}$ mice. Concomitantly, frequencies of IFN- $\gamma$ producers as well as cytolytic activities in response to $\operatorname{TcR} \alpha / \beta$ ligation were reduced in these mutants. Yet, this reduction in biological activities was less pronounced, as could have been expected from flow cytometric analysis. These findings suggest that, at least in the absence of $\beta 2 \mathrm{~m}$, the CD8 $\beta^{-}$i-IEL are potent IFN- $\gamma$ producers and killer cells.

Mucosal host defense primarily involves production and transcytosis to the gut lumen of secretory $\operatorname{IgA}$ as well as regional activation of professional phagocytes, macrophages, and polymorphonuclear leukocytes (23). IFN- $\gamma$ is a potent activator of professional phagocytes and, moreover, has been shown to promote expression of the IgA secretory component in epithelial cells (38). Furthermore, IFN- $\gamma$ could induce MHC II expression in intestinal cells and thus promote antigen presentation by these cells to $\mathrm{CD}^{+}{ }^{+} \mathrm{T}$ cells $(40,48)$. Finally, prompt IFN- $\gamma$ secretion by $\mathrm{i}-\mathrm{IEL}$ in response to intestinal listeriosis could contribute to a cytokine milieu which favors development of Th1 cells. This assumption is based on increasing evidence that the development of protective Th1 cells is markedly promoted by early IFN- $\gamma$ secretion from other leukocytes (36). Although we consider IFN- $\gamma$ secretion by i-IEL to be 

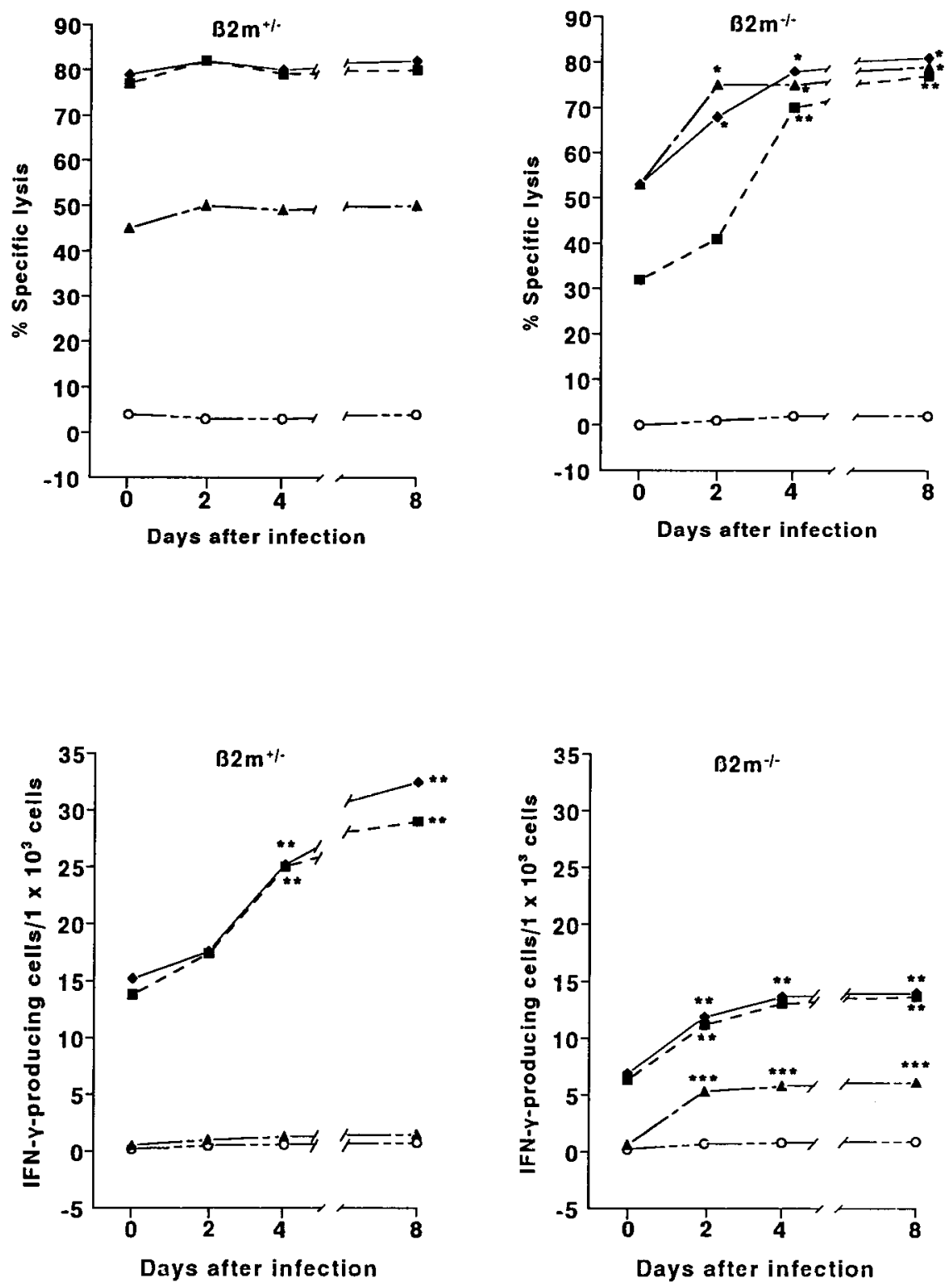

FIG. 2. Kinetics of cytolytic activities and frequencies of IFN- $\gamma$-producing cells among i-IEL from $\beta 2 \mathrm{~m}^{-/-}$and $\beta 2 \mathrm{~m}^{+/-}$mice during intestinal L. monocytogenes infection. Mice were infected p.o. with $10^{8}$ L. monocytogenes organisms, and i-IEL were prepared on day $0,2,4$, or 8 postinfection. Cytotoxic activities of i-IEL (top graphs, effector-to-target ratio $=100: 1)$ and frequencies of IFN- $\gamma$-producing cells among i-IEL (bottom graphs) were determined after stimulation with anti-CD3 MAb $(\bullet)$, anti-TcR $\alpha / \beta \mathrm{MAb}(\boldsymbol{\square})$, anti-TcR $\gamma / \delta \mathrm{MAb}(\boldsymbol{\Lambda})$, or normal hamster $\operatorname{Ig}(\bigcirc)$. Results are means for a total of four mice per group. $*$, **, and $* * *$, significant difference relative to uninfected mice at $P<0.05, P<0.01$, and $P<0.001$, respectively. For further details, see Table 1 and the legend to Fig. 1.

important for mucosal defense against bacterial invasion from the intestine, we envisage that, in addition, cytolytic activities may contribute to mucosal resistance. In contrast to many other bacterial pathogens, invasion by L. monocytogenes is not restricted to $M$ cells but seems to proceed through enterocytes as well (33). Lysis of infected enterocytes could interfere with bacterial invasion.

The $\beta 2 \mathrm{~m}$ is required for surface expression of the classical MHC I $\alpha$ chain as well as of numerous "MHC I-like" molecules, including CD1 and TL $(37,41,45)$. MHC I molecules present antigenic peptides to $\mathrm{CD} 8 \alpha / \beta^{+} \mathrm{T}$ cells, whereas the MHC I-like molecules serve as important presenting molecules for $\mathrm{TcR} \gamma / \delta$ cells (15) and some $\mathrm{TcR} \alpha / \beta$ cells, such as doublenegative TcR $\alpha / \beta$ cells $(4,28,29), \mathrm{CD}^{+}{ }^{+} \mathrm{NK} 1.1^{+} \mathrm{TcR} \alpha / \beta$ cells
(5), and CD $8 \alpha / \alpha^{+}$TcR $\alpha / \beta$ cells (1). The $\beta 2 \mathrm{~m}$-associated MHC I-like molecules of the CD1 family are expressed in high density by intestinal epithelial cells and present antigenic ligands to $\operatorname{CD} 8 \alpha / \alpha^{+}$i-IEL $(6,27)$. Our experiments revealed a definite though not complete reduction of $\mathrm{CD} 8 \alpha / \alpha^{+} \mathrm{TcR} \alpha / \beta$, but not TcR $\gamma / \delta$, i-IEL in $\beta 2 \mathrm{~m}^{-1-}$ mice. This may mean that the $\mathrm{CD} 8 \alpha / \alpha^{+} \mathrm{TcR} \alpha / \beta$ i-IEL encompasses MHC I-like-dependent and -independent subsets and that all TcR $\gamma / \delta$ i-IEL are independent. Our findings that intestinal listeriosis stimulated $\mathrm{TcR} \alpha / \beta$ and TcR $\gamma / \delta$ i-IEL from $\beta 2 \mathrm{~m}^{-/-}$mutants exclude activation by $\beta 2 \mathrm{~m}$-associated classical MHC I and MHC I-like molecules, including CD1. Two alternative activation mechanisms are considered. First, some MHC I-like molecules are surface expressed independently of $\beta 2 \mathrm{~m}$ and, therefore, could 
TABLE 2. Phenotypes of i-IEL from $\beta 2 \mathrm{~m}^{-1-}$ and $\beta 2 \mathrm{~m}^{+/-}$mice and influence of intestinal L. monocytogenes infection ${ }^{a}$

\begin{tabular}{|c|c|c|c|c|c|c|c|}
\hline \multirow{3}{*}{ Group $^{b}$} & \multicolumn{3}{|c|}{ Surface phenotype } & \multicolumn{4}{|c|}{$\%$ Lymphoid cells in mutant mice } \\
\hline & \multirow{2}{*}{$\mathrm{CD} 4$} & \multirow{2}{*}{$\mathrm{CD} 8 \alpha$} & \multirow{2}{*}{$\mathrm{CD} 8 \beta$} & \multicolumn{2}{|c|}{ Uninfected } & \multicolumn{2}{|c|}{ Infected } \\
\hline & & & & $\beta 2 \mathrm{~m}^{+/-}$ & $\beta 2 \mathrm{~m}^{-/-}$ & $\beta 2 \mathrm{~m}^{+/-}$ & $\beta 2 \mathrm{~m}^{-/-}$ \\
\hline A & - & - & - & $3.4 \pm 3.9$ & $5.8 \pm 4.8$ & $8.4 \pm 5.3$ & $6.4 \pm 4.9$ \\
\hline B & + & - & - & $4.3 \pm 2.4$ & $5.1 \pm 1.8$ & $7.5 \pm 2.4$ & $3.9 \pm 1.8$ \\
\hline $\mathrm{C}$ & + & + & - & $4.4 \pm 1.5$ & $2.3 \pm 1.8$ & $2.2 \pm 0.4$ & $1.0 \pm 0.3$ \\
\hline $\mathrm{D}$ & + & + & + & $\mathrm{ND}^{c}$ & ND & ND & ND \\
\hline $\mathrm{E}$ & - & + & - & $21.0 \pm 8.4$ & $0.5 \pm 0.1^{d}$ & $14.7 \pm 4.1$ & $2.1 \pm 1.2$ \\
\hline $\mathrm{F}$ & - & + & + & $25.3 \pm 8.1$ & $\mathrm{ND}^{d}$ & $19.5 \pm 4.7$ & ND \\
\hline G & - & - & - & $0.5 \pm 0.3$ & $1.2 \pm 0.5$ & $0.8 \pm 0.5$ & $1.1 \pm 0.9$ \\
\hline $\mathrm{H}$ & + & - & - & ND & ND & ND & ND \\
\hline I & + & + & - & ND & ND & ND & ND \\
\hline $\mathrm{J}$ & + & + & + & ND & ND & ND & ND \\
\hline $\mathrm{K}$ & - & + & - & $30.4 \pm 14.3$ & $67.7 \pm 12.1^{e}$ & $33.9 \pm 4.1$ & $70.2 \pm 14.3$ \\
\hline $\mathrm{L}$ & - & + & + & ND & ND & ND & ND \\
\hline $\mathrm{M}$ & - & - & - & $4.0 \pm 4.1$ & $6.8 \pm 3.9$ & $4.9 \pm 0.9$ & $5.6 \pm 2.1$ \\
\hline
\end{tabular}

${ }^{a}$ Mice were infected p.o. with $10^{8}$ L. monocytogenes organisms. The i-IEL were prepared on day 0 and day 8 postinfection and double or triple stained. Data from three different experiments, means \pm standard deviations for 10 mice, are shown.

${ }^{b}$ Groups: A, B220 ${ }^{+}$cells; B, CD4 ${ }^{+} \mathrm{CD} 8 \alpha^{-}$TcR $\alpha / \beta$ cells; C, $\left(\mathrm{CD} 4^{+} \mathrm{CD} 8 \alpha^{+} \mathrm{TcR} \alpha / \beta\right.$ cells $)-\left(\mathrm{CD} 4^{+} \mathrm{CD} 8 \beta^{+} \mathrm{TcR} \alpha / \beta\right.$ cells); D, CD4 ${ }^{+} \mathrm{CD} 8 \beta^{+}$TcR $\alpha / \beta$ cells; E, $\left(\mathrm{CD} 4^{-} \mathrm{CD} 8 \alpha^{+} \mathrm{TcR} \alpha / \beta\right.$ cells) $-\left(\mathrm{CD} 4^{-} \mathrm{CD} 8 \beta^{+} \mathrm{TcR} \alpha / \beta\right.$ cells); F, CD4 ${ }^{-} \mathrm{CD} 8 \beta^{+} \mathrm{TcR} \alpha / \beta$ cells; G, CD4- CD $8 \alpha^{-} \mathrm{TcR} \alpha / \beta$ cells; H, CD4 ${ }^{+} \mathrm{CD} 8 \alpha^{-}$TcR $\gamma / \delta$ cells; I, $\left(\mathrm{CD} 4{ }^{+} \mathrm{CD} 8 \alpha^{+} \mathrm{TcR} \gamma / \delta\right.$ cells $)-\left(\mathrm{CD} 4{ }^{+} \mathrm{CD} 8 \beta^{+} \mathrm{TcR} \gamma / \delta\right.$ cells $) ; \mathrm{J}, \mathrm{CD} 4^{+} \mathrm{CD} 8 \beta^{+} \mathrm{TcR} \gamma / \delta$ cells; $\mathrm{K},\left(\mathrm{CD} 4{ }^{-} \mathrm{CD} 8 \alpha^{+} \mathrm{TcR} \gamma / \delta\right.$ cells $)-\left(\mathrm{CD} 4^{-} \mathrm{CD} 8 \beta^{+} \mathrm{TcR} \gamma / \delta\right.$ cells $) ; \mathrm{L}$, $\mathrm{CD} 4^{-} \mathrm{CD} 8 \beta^{+} \mathrm{TcR} \gamma / \delta$ cells; $\mathrm{M}, \mathrm{CD} 4^{-} \mathrm{CD} 8 \alpha^{-}$TcR $\gamma / \delta$ cells.

${ }^{c} \mathrm{ND}$, not detectable.

${ }^{d}$ Significant difference relative to uninfected $\beta 2 \mathrm{~m}^{+/-}$mice at $P<0.001$.

${ }^{e}$ Significant difference relative to uninfected $\beta 2 \mathrm{~m}^{+/-}$mice at $P<0.01$.

participate in the activation of i-IEL in $\beta 2 \mathrm{~m}^{-1-}$ mice. Alternatively, these i-IEL could be activated independently of TcRligand interactions in vivo, e.g., through inflammatory cytokines. Because of the rapid activation of i-IEL in $\beta 2 \mathrm{~m}^{-/-}$mice, we favor the latter alternative.

Surface expression of neonatal Fc receptor also depends on $\beta 2 \mathrm{~m}$ association (37). The neonatal $\mathrm{Fc}$ receptor participates in IgA transcytosis into the gut lumen (37). Although we consider the possibility that deficient neonatal Fc receptor expression affects mucosal protection in $\beta 2 \mathrm{~m}^{-/-}$mice, we have thus far no evidence for increased translocation of normal gut flora nor for increased susceptibility to intestinal listeriosis in $\beta 2 \mathrm{~m}^{-1-} \mathrm{mu}-$ tants (unpublished data). Careful studies on this subject will be performed in the future.

The i-IEL express potent cytolytic activities and synthesize various cytokines directly in response to TcR ligation without intentional preactivation $(10,42,44)$. Such preactivation is probably caused by continuous encounter with the normal intestinal flora (2). Our experiments, showing potent cytolytic activity and IFN- $\gamma$ production by i-IEL both in $\beta 2 \mathrm{~m}^{+/-}$and in $\beta 2 \mathrm{~m}^{-1-}$ mice, are consistent with preactivation of $\mathrm{i}$-IEL by the normal gut flora independent of $\beta 2 \mathrm{~m}$ expression. Yet, our data reveal further elevation of biological activities by TcR $\gamma / \delta$ i-IEL at an inoculum dose which results in host invasion from the intestine (47). Thus, the i-IEL were not exhausted and could be stimulated further by invasive pathogens.

Frequencies of IFN- $\gamma$-producing TcR $\gamma / \delta$ i-IEL were low in uninfected $\beta 2 \mathrm{~m}^{+/-}$and $\beta 2 \mathrm{~m}^{-1-}$ mice compared with those of $\mathrm{TcR} \alpha / \beta$ i-IEL. In response to listeriosis, frequencies of IFN$\gamma$-producing $\mathrm{TcR} \gamma / \delta \mathrm{i}$-IEL were increased 2 - to 3 -fold in $\beta 2 \mathrm{~m}^{+/-}$mice and 10 -fold in $\beta 2 \mathrm{~m}^{-1-}$ mice. This differential activation of TcR $\gamma / \delta$ i-IEL in $\beta 2 \mathrm{~m}^{+/-}$and $\beta 2 \mathrm{~m}^{-/-}$mice could mean that TcR $\gamma / \delta$ i-IEL are inhibited by $\beta 2 \mathrm{~m}$. Evidence that $\mathrm{TcR} \gamma / \delta$ i-IEL encompass a large fraction of autoreactive $\mathrm{T}$ cells which are controlled locally in the intestine has been presented (25). Recently, inhibitory receptors which interact with conserved parts of the MHC I molecule have been identified on activated NK cells and on cytotoxic T lymphocytes (3).
It is possible that such inhibitory mechanisms prevent uncontrolled activation of TcR $\gamma / \delta$ i-IEL in immunocompetent mice. Obviously, in the absence of $\beta 2 \mathrm{~m}$, such inhibitory signals cannot be transmitted, thus causing potent activation of $\mathrm{TcR} \gamma / \delta$ $\mathrm{i}$-IEL to intestinal listeriosis in $\beta 2 \mathrm{~m}^{-/-}$mice.

In summary, our findings demonstrate that intestinal listeriosis increases biological activities in i-IEL, in particular IFN- $\gamma$ production in the presence or in the absence of $\beta 2 \mathrm{~m}$. Hence, $\mathrm{CD} 8 \alpha / \alpha^{+} \mathrm{TcR} \gamma / \delta$ i-IEL and a large proportion of CD $8 \alpha / \alpha^{+}$ $\mathrm{TcR} \alpha / \beta$ i-IEL not only develop independently of $\beta 2 \mathrm{~m}$, but their functional activation by invading bacterial pathogens also occurs independently of $\beta 2 \mathrm{~m}$. Rapid activation of these i-IEL could contribute to immune surveillance against bacterial invasion at the mucosal barrier.

\section{ACKNOWLEDGMENTS}

We are grateful to R. Jaenisch for breeding pairs of mutant mice and to L. Lefrancois, R. Kubo, J. A. Bluestone, and M. Pierres for helpful reagents. We thank $\mathrm{K}$. Tell for MAb production and R. Mahmoudi and A. Gritzan for excellent secretarial assistance.

This work received financial support from the Deutsche Forschungsgemeinschaft (SFB 322 and Ka 573/3-1). M. Emoto acknowledges financial support from the Nitto Foundation and the Mochida Memorial Foundation for Medical and Pharmaceutical Research.

\section{REFERENCES}

1. Balk, S. P., E. C. Ebert, R. L. Blumenthal, F. V. McDermott, K. W. Wucherpfennig, S. B. Landau, and R. S. Blumberg. 1991. Oligoclonal expansion and CD1 recognition by human intestinal intraepithelial lymphocytes. Science 253:1411-1415.

2. Bandeira, A., T. Mota-Santos, S. Itohara, S. Degermann, C. Heusser, S. Tonegawa, and A. Coutinho. 1990 . Localization of $\gamma / \delta$ T cells to the intestinal epithelium is independent of normal microbial colonization. J. Exp. Med. 172:239-244.

3. Barinaga, M. 1995. Researchers find molecules that muzzle killer cells. Science 268:367-368.

4. Beckman, E. M., S. A. Porcelli, C. T. Morita, S. M. Behar, S. T. Furlong, and M. B. Brenner. 1994. Recognition of a lipid antigen by CD1-restricted $\alpha \beta^{+}$ T cells. Nature (London) 372:691-694

5. Bendelac, A., O. Lantz, M. E. Quimby, J. W. Yewdell, J. R. Bennink, and 
R. R. Brutkiewicz. 1995. CD1 recognition by mouse NK1 ${ }^{+}$T lymphocytes. Science 268:863-865.

6. Bleicher, P. A., S. P. Balk, S. J. Hagen, R. S. Blumberg, T. J. Flotte, and C. Terhorst. 1990. Expression of murine CD1 on gastrointestinal epithelium. Science 250:679-682.

7. Correa, I., M. Bix, N.-S. Liao, M. Zijlstra, R. Jaenisch, and D. Raulet. 1992. Most $\gamma / \delta$ T cells develop normally in $\beta 2$-microglobulin-deficient mice. Proc. Natl. Acad. Sci. USA 89:653-657.

8. Fleming, D. W., S. L. Cochi, K. L. MacDonald, J. Brondum, P. S. Hayes, B. D. Plikaytis, M. B. Holmes, A. Audurier, C. V. Broome, and A. L. Reingold. 1985. Pasteurized milk as a vehicle of infection in an outbreak of listeriosis. N. Engl. J. Med. 312:404-407.

9. Golstein, P., C. Goridis, A.-M. Schmitt-Verhulst, B. Hayot, A. Pierres, A. van Agthoven, Y. Kaufmann, Z. Eshhar, and M. Pierres. 1982. Lymphoid cell surface interaction structures detected using cytolysis-inhibiting monoclonal antibodies. Immunol. Rev. 68:5-42.

10. Goodman, T., and L. Lefrançois. 1988. Expression of the $\gamma / \delta$ T-cell receptor on intestinal $\mathrm{CD}^{+}$intraepithelial lymphocytes. Nature (London) 333:855858

11. Goodman, T., and L. Lefrançois. 1989. Intraepithelial lymphocytes. Anatomical site, not $\mathrm{T}$ cell receptor form, dictates phenotype and function. J. Exp. Med. 170:1569-1581.

12. Guy-Grand, D., M. Malassis-Seris, C. Briottet, and P. Vassalli. 1991. Cytotoxic differentiation of mouse gut thymodependent and independent intraepithelial T lymphocytes is induced locally. Correlation between functional assays, presence of perforin and granzyme transcripts, and cytoplasmic granules. J. Exp. Med. 173:1549-1552.

13. Guy-Grand, D., B. Rocha, and P. Vassalli. 1993. Origin and development of gut intraepithelial lymphocytes, p. 21-31. In H. Kiyono and J. R. McGhee (ed.), Advances in host defense mechanisms, vol. 9. Mucosal immunology: intraepithelial lymphocytes. Raven Press Ltd., New York.

14. Guy-Grand, D., and P. Vassalli. 1993. Gut intraepithelial T lymphocytes. Curr. Opin. Immunol. 5:247-252.

15. Haas, W., P. Pereira, and S. Tonegawa. 1993. Gamma/delta cells. Annu. Rev. Immunol. 11:637-685.

16. Ishikawa, H., Y. Li, A. Abeliovich, S. Yamamoto, S. H. E. Kaufmann, and S. Tonegawa. 1993. Cytotoxic and interferon $\gamma$-producing activities of $\gamma / \delta \mathrm{T}$ cells in the mouse intestinal epithelium are strain dependent. Proc. Natl. Acad. Sci. USA 90:8204-8208.

17. Kaufmann, S. H. E. 1993. Immunity to intracellular bacteria. Annu. Rev. Immunol. 11:129-163.

18. Klein, J. R., and R. L. Mosley. 1993. Phenotypic and cytotoxic characteristics of intraepithelial lymphocytes, p. 33-60. In H. Kiyono and J. R. McGhee (ed.), Advances in host defense mechanisms, vol. 9. Mucosal immunology: intraepithelial lymphocytes. Raven Press Ltd., New York.

19. Kubo, R. T., W. Born, J. W. Kappler, P. Marrack, and M. Pigeon. 1989. Characterization of a monoclonal antibody which detects all murine $\alpha \beta \mathrm{T}$ cell receptors. J. Immunol. 142:2736-2742.

20. Lefrançois, L. 1991. Extrathymic differentiation of intraepithelial lymphocytes: generation of a separate and unequal T-cell repertoire? Immunol. Today 12:436-438

21. Leo, O., M. Foo, D. H. Sachs, L. E. Samelson, and J. A. Bluestone. 1987. Identification of a monoclonal antibody specific for a murine $\mathrm{T} 3$ polypeptide. Proc. Natl. Acad. Sci. USA 84:1374-1378.

22. Linnan, M. J., L. Mascola, X. D. Lou, V. Goulet, S. May, C. Salminen, D. W. Hird, M. L. Yonekura, P. Hayes, R. Weaver, A. Andurier, B. D. Plikaytis, S. L. Fannin, A. Kleks, and C. V. Broome. 1988. Epidemic listeriosis associated with Mexican-style cheese. N. Engl. J. Med. 319:823-828.

23. Mestecky, J., and J. R. McGhee. 1987. Immunoglobulin A (IgA): molecular and cellular interactions involved in IgA biosynthesis and immune response. Adv. Immunol. 40:153-245.

24. Möller, S. A., and C. A. Borrebaeck. 1985. A filter immuno-plaque assay for the detection of antibody-secreting cells in vitro. J. Immunol. Methods 79: 195-204.

25. Nagler-Anderson, C., L. A. McNair, and A. Cradock. 1992. Self-reactive, T cell receptor- $\gamma \delta^{+}$, lymphocytes from the intestinal epithelium of weanling mice. J. Immunol. 149:2315-2322.
26. Neuhaus, O., M. Emoto, C. Blum, S. Yamamoto, and S. H. E. Kaufmann. 1995. Control of thymus-independent intestinal intraepithelial lymphocytes by $\beta 2$-microglobulin. Eur. J. Immunol. 25:2332-2339.

27. Porcelli, S. A. 1995 . The CD1 family: a third lineage of antigen-presenting molecules. Adv. Immunol. 59:1-98.

28. Porcelli, S., M. B. Brenner, J. L. Greenstein, S. P. Balk, C. Terhorst, and P. A. Bleicher. 1989. Recognition of cluster of differentiation 1 antigens by human $\mathrm{CD}^{-} \mathrm{CD}^{-}$cytolytic T lymphocytes. Nature (London) 341:447-450.

29. Porcelli, S., C. T. Morita, and M. B. Brenner. 1992. CD1b restricts the response of human $\mathrm{CD}^{-} 8^{-} \mathrm{T}$ lymphocytes to a microbial antigen. Nature (London) 360:593-597.

30. Poussier, P., and M. Julius. 1993. Maturation of $T$ cells in the intestinal epithelium. Immunol. Today 14:140.

31. Poussier, P., and M. Julius. 1994. Thymus independent T cell development and selection in the intestinal epithelium. Annu. Rev. Immunol. 12:521-553.

32. Prat, M., G. Gribaudo, P. M. Comoglio, G. Cavallo, and S. Landolfo. 1984 Monoclonal antibodies against murine $\gamma$ interferon. Proc. Natl. Acad. Sci. USA 81:4515-4519.

33. Racz, P., K. Tenner, and E. Mero. 1972. Experimental listeria enteritis. I. An electron microscopic study of the epithelial phase in experimental listeria infection. Lab. Invest. 26:694-700.

34. Schlech, W. F., P. M. Lavigne, R. A. Bortolussi, A. C. Allen, E. V. Haldane, A. J. Wort, A. W. Hightower, S. E. Johnson, S. H. King, E. S. Nicholls, and C. V. Broome. 1983. Epidemic listeriosis-evidence for transmission by food. N. Engl. J. Med. 308:203-206.

35. Schleussner, C., and R. Ceredig. 1993. Analysis of intraepithelial lymphocytes from major histocompatibility complex (MHC)-deficient mice: no evidence for a role of MHC class II antigens in the positive selection of $\mathrm{V} \delta 4^{+}$ $\gamma / \delta$ T cells. Eur. J. Immunol. 23:1615-1622.

36. Seder, R. A., and W. E. Paul. 1994. Acquisition of lymphokine-producing phenotype by $\mathrm{CD}^{+} \mathrm{T}$ cells. Annu. Rev. Immunol. 12:635-673.

37. Shawar, S. M., J. M. Vyas, J. R. Rodgers, and R. R. Rich. 1994. Antigen presentation by major histocompatibility complex class I-b molecules. Annu. Rev. Immunol. 12:839-880.

38. Sollid, L. M., D. Kvale, P. Brandtzaeg, G. Markussen, and E. Thorsby. 1987. Interferon- $\gamma$ enhances expression of secretory component, the epithelial receptor for polymeric immunoglobulins. J. Immunol. 138:4303-4306.

39. Spitalny, G. L., and E. A. Havell. 1984. Monoclonal antibody to murine gamma interferon inhibits lymphokine-induced antiviral and macrophage tumoricidal activities. J. Exp. Med. 159:1560-1565.

40. Steiniger, B., P. Falk, M. Lohmüller, and P. H. van der Meide. 1989. Class II MHC antigens in the rat digestive system. Normal distribution and induced expression after interferon-gamma treatment in vivo. Immunology 68:507-513.

41. Stroynowski, I. 1990. Molecules related to class I major histocompatibility complex antigens. Annu. Rev. Immunol. 8:501-530.

42. Taguchi, T., J. R. McGhee, R. L. Coffman, K. W. Beagley, J. H. Eldridge, K. Takatsu, and H. Kiyono. 1990. Analysis of Th1 and Th2 cells in murine gut-associated tissues. Frequencies of $\mathrm{CD}^{+}{ }^{+}$and $\mathrm{CD} 8^{+} \mathrm{T}$ cells that secrete IFN- $\gamma$ and IL-5. J. Immunol. 145:68-77.

43. Teixeira, H. C., and S. H. E. Kaufmann. 1994. Role of NK1.1 ${ }^{+}$cells in experimental listeriosis. NK1 ${ }^{+}$cells are early IFN- $\gamma$ producers but impair resistance to Listeria monocytogenes infection. J. Immunol. 152:1873-1882.

44. Viney, J. L., P. J. Kilshaw, and T. T. MacDonald. 1990. Cytotoxic $\alpha / \beta^{+}$and $\gamma / \delta^{+}$T cells in murine intestinal epithelium. Eur. J. Immunol. 20:1623-1626.

45. von Boehmer, H. 1990. Developmental biology of T cells in T cell-receptor transgenic mice. Annu. Rev. Immunol. 8:531-556.

46. von Boehmer, H., W. Swat, and P. Kisielow. 1993. Positive selection of immature $\alpha \beta$ T cells. Immunol. Rev. 135:67-79.

47. Yamamoto, S., F. Russ, H. C. Teixeira, P. Conradt, and S. H. E. Kaufmann 1993. Listeria monocytogenes-induced gamma interferon secretion by intestinal intraepithelial $\gamma / \delta$ T lymphocytes. Infect. Immun. 61:2154-2161.

48. Zhang, Z., and J. G. Michael. 1990. Orally inducible immune unresponsiveness is abrogated by IFN- $\gamma$ treatment. J. Immunol. 144:4163-4165.

49. Zijlstra, M., M. Bix, N. E. Simister, J. M. Loring, D. H. Raulet, and R. Jaenisch. 1990. $\beta 2$-microglobulin deficient mice lack CD4 ${ }^{-} 8^{+}$cytolytic T cells. Nature (London) 344:742-746.

Editor: D. H. Howard 